ARTICLE

\title{
Manipulating interstitial carbon atoms in the nickel octahedral site for highly efficient hydrogenation of alkyne
}

\author{
Yiming Niu (1) ${ }^{1,2}$, Xing Huang (i] ${ }^{3,4}$, Yongzhao Wang ${ }^{1,2}$, Ming $X u^{5}$, Junnan Chen ${ }^{1,2}$, Shuliang $\mathrm{Xu}^{6}$,

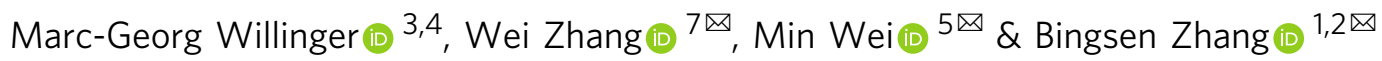

Light elements in the interstitial site of transition metals have strong influence on heterogeneous catalysis via either expression of surface structures or even direct participation into reaction. Interstitial atoms are generally metastable with a strong environmental dependence, setting up giant challenges in controlling of heterogeneous catalysis. Herein, we show that the desired carbon atoms can be manipulated within nickel ( $\mathrm{Ni}$ ) lattice for improving the selectivity in acetylene hydrogenation reaction. The radius of octahedral space of $\mathrm{Ni}$ is expanded from 0.517 to $0.524 \AA$ via formation of $\mathrm{Ni}_{3} \mathrm{Zn}$, affording the dissociated carbon atoms to readily dissolve and diffuse at mild temperatures. Such incorporated carbon atoms coordinate with the surrounding $\mathrm{Ni}$ atoms for generation of $\mathrm{Ni}_{3} \mathrm{ZnC}_{0.7}$ and thereof inhibit the formation of subsurface hydrogen structures. Thus, the selectivity and stability are dramatically improved, as it enables suppressing the pathway of ethylene hydrogenation and restraining the accumulation of carbonaceous species on surface.

\footnotetext{
${ }^{1}$ Shenyang National Laboratory for Materials Science, Institute of Metal Research, Chinese Academy of Sciences, 110016 Shenyang, China. ${ }^{2}$ Department of Materials Science and Engineering, University of Science and Technology of China, 230026 Hefei, China. ${ }^{3}$ Department of Inorganic Chemistry, Fritz Haber Institute of the Max Planck Society, 14195 Berlin, Germany. ${ }^{4}$ Scientific Center for Optical and Electron Microscopy, Otto-Stern-Weg 3, ETH Zurich, 8093 Zurich, Switzerland. ${ }^{5}$ State Key Laboratory of Chemical Resource Engineering, Beijing Advanced Innovation Center for Soft Matter Science and Engineering, Beijing University of Chemical Technology, 100029 Beijing, China. ${ }^{6}$ Dalian National Laboratory for Clean Energy, Dalian Institute of Chemical Physics, Chinese Academy of Sciences, 116023 Dalian, China. ${ }^{7}$ Electron Microscopy Center, Key Laboratory of Automobile Materials MOE, and School of Materials

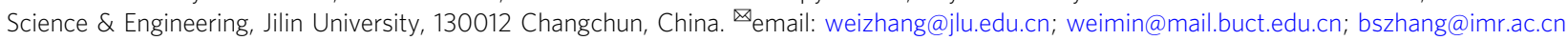


nterstitial sites of transition metal catalyst are found to be occupied by dissociated atoms under a high chemical potential of reactant molecules ${ }^{1-4}$. Definitely, the interstitial atoms enable modifying electronic/geometric properties of surface atoms, which directly affects its Fermi level and density of states. Thus, the catalytic behaviors were tuned. For instance, the subsurface $\mathrm{O}$ in $\mathrm{Cu}$ nanoparticles (NPs) $(\sim 10 \mathrm{~nm})$ impairs a positive charge to the $\mathrm{Cu}$ surface and thereof improves the catalytic performance in methanol steam reforming reaction ${ }^{5}$. More interestingly, the interstitial atoms are clarified to directly participate in reactions and afford the distinct reaction pathways from the surface-adsorbed atoms. So it leads to diverse products, reaction kinetics, and mechanisms. As evidenced by Ceyer et al. ${ }^{2}$, the interstitial $\mathrm{H}$ in $\mathrm{Ni}$ subsurface is found to be active for hydrogenation adsorbed $\mathrm{CH}_{3}$ to $\mathrm{CH}_{4}$ whereas the surfaceadsorbed $\mathrm{H}$ remains unreactive with $\mathrm{CH}_{3}$ species. Initially, the interstitial site manipulated catalysis is considered to affect a few metal catalysts and associated reactions. More transition metalcatalyzed reactions, however, are controlled by the generation of metastable interstitial atoms ${ }^{6-9}$. Thus, it is of great interests to explore the control of interstitial site atoms in transition metal catalysts for tuning their catalytic performances ${ }^{10-12}$.

Acetylene selective hydrogenation, a well-known industrial reaction, with which a switchable selectivity towards distinct products is determined by the alternation of interstitial atoms in Pd catalyst ${ }^{1,13-15}$. Experimental studies demonstrated that carbon or hydrogen atoms in the interstitial sites of Pd subsurface govern the selectivity to alkene or alkane ${ }^{1,16}$. Similar results were also observed in $\mathrm{Ni}$, which is widely adopted as industrial hydrogenation catalyst (e.g., Raney Ni) for high activity and low cost in other heterogeneous reactions. However, it suffers from the drawbacks of low selectivity and stability in alkyne selective hydrogenation reaction ${ }^{17,18}$. Some investigations demonstrate that interstitial $\mathrm{H}$ atoms can readily hydrogenate adsorbed $\mathrm{C}_{2} \mathrm{H}_{4}$ to $\mathrm{C}_{2} \mathrm{H}_{6}$. It drives $\mathrm{C}_{2} \mathrm{H}_{4}$ from underneath with an orientation to the rehybridized $\pi$ orbitals, although the surface $\mathrm{H}$ atoms remain unreactive $^{19}$. These results reveal that it is the occupation of interstitial sites with carbon atom that is responsible, instead of hydrogen atoms, in Ni group catalysts. Following this behavior, the selectivity would be improved in hydrogenation. Thus, the formation of subsurface interstitial atoms was thereof focused on. Unfortunately, it is highly kinetically dependent and suffers from an input of external energies to stabilize; it remains challenging for the atomic-level control of desired atoms ${ }^{14,20}$. The common strategy to stabilize the metastable interstitial structure lies at construction of an encapsulated shell. Following this approach, $\mathrm{PdC}_{\mathrm{x}} @ \mathrm{C}$ structure was successfully prepared with the removal of the graphite layers after external procedures ${ }^{21}$. However, it is even difficult for the formation of Ni-based interstitial carbon structure because of the usually required high temperatures. The dissolved carbon atoms within $\mathrm{Ni}$ lattices are readily segregated on the surface. As a result, it offers the formation of graphite layers or even carbon nanotubes/nanofibers (CNTs/CNFs) under reaction conditions. Following the removal of carbon shells is even more challenging, during which $\mathrm{Ni}$ is readily oxidized and the interstitial carbon structure is damaged due to the oxyphilic nature of $\mathrm{Ni}$. That is to say, it is crucial to modulate Ni environments in order to accommodate carbon atoms with directly exposed active surfaces instead of applying external process.

In general, the interstitial atoms prefer to locate in octahedral hole than at tetrahedral sites in view of the larger space with more available coordination atoms ${ }^{22}$. The radius of octahedral $\left(R_{\text {oct }}\right)$ site in face-centered cubic (FCC) metals can be calculated by following the equation $R_{\text {oct }}=0.414 R_{\mathrm{M}}\left(R_{\mathrm{M}}\right.$ represents the metallic radius of metal atom $)^{23}$. Compared with Pd $(0.569 \AA)$, the smaller $R_{\text {oct }}$ in Ni $(0.517 \AA)$ leads partially to both a higher carbon dissolving temperature and an easier segregated carbon atom on surface. Therefore, a structural transformation from $\mathrm{Ni}$ (FCC) to $\mathrm{Ni}_{3} \mathrm{C}$ (hexagonal close-packed structure) occurs to accommodate a certain amount of carbon atoms, together with uncontrollable formation of graphitic layers ${ }^{24,25}$. Theoretical studies have evidenced that the expansion of metal lattice parameters leads readily to inclusion and diffusion of atoms at interstitial sites ${ }^{26-28}$. Second metal introduction can effectively tune the lattice parameter of $\mathrm{Ni}^{29,30}$. In addition, the electronic structure should not be changed in order to maintain the capability of $\mathrm{Ni}$ to dissociate adsorbed molecules. In $\mathrm{Ni}-\mathrm{Zn}$ systems a $\mathrm{Zn}$ addition may expand the lattice parameters of $\mathrm{Ni}$ and generally leave a slightly modified electronic structure $^{30,31}$

Herein, $R_{\text {oct }}$ increases from 0.517 to $0.524 \AA$, provided if 25 at $\%$ $\mathrm{Zn}$ is introduced to $\mathrm{Ni}$ to form $\mathrm{Ni}_{3} \mathrm{Zn}$, with a marginal change of electronic structure. Simple impregnation method and hydrogen/ acetylene treatment (the procedures are illustrated in Supplementary Fig. 1) readily generate the interstitial carbon structure $\mathrm{Ni}_{3} \mathrm{ZnC}_{0.7}$ at low temperature, characterized by integrating in situ and ex situ techniques. It demonstrates that the supported $\mathrm{Ni}_{3} \mathrm{ZnC}_{0.7}$ catalyst exhibits high selectivity at different ratios of $\mathrm{H}_{2}$ /alkyne and an excellent stability in acetylene hydrogenation reaction. The dramatic improvement is ascribed to two issues: the interstitial carbon modulation of $\mathrm{Ni}$ surface/subsurface structures and the suppressed accumulation of carbonaceous fragments on the surface.

\section{Results}

Incorporation of carbon atom into $\mathrm{Ni}$. Carbon materials with abundant defects, since providing additional chemical potential of carbon, are selected to probably diffuse and stabilize carbon in the interstitial sites of supported Ni-based structure ${ }^{32}$. In order to well disperse $\mathrm{Ni}$ and $\mathrm{Zn}$ ions, oxidized carbon nanotube (oCNT) is optimized for its high surface area and adjustable homogeneous functional sites ${ }^{33}$. Other generally adopted supports such as highsurface-area $\mathrm{Al}_{2} \mathrm{O}_{3}$ is also an ideal candidate, but the desired structure has been not obtained (Supplementary Fig. 2). For the preparation process, $\mathrm{Ni}$ or stoichiometric $\mathrm{Ni} / \mathrm{Zn}$ salts were uniformly impregnated on oCNT (Supplementary Fig. 3) and subjected to a temperature ramp under hydrogen atmosphere. During the reduction process, Ni promoted the reduction of $\mathrm{Zn}$ ions and contributed to the formation of $\mathrm{Ni}_{3} \mathrm{Zn}$ structure at $500{ }^{\circ} \mathrm{C}$ under hydrogen atmosphere, as evidenced by in situ X-ray diffraction (XRD) experiments in Supplementary Fig. 4. A supported $\mathrm{Ni}$ catalyst was also reduced at $500{ }^{\circ} \mathrm{C}$ for reference. The lattice parameter of $\mathrm{Ni}$ increased from 3.562 to $3.582 \AA$ via the formation of $\mathrm{Ni}_{3} \mathrm{Zn}$ structure, as shown by the diffraction peak shifting from $44.5^{\circ}$ to $43.7^{\circ}$ of (111) plane in XRD patterns (Supplementary Fig. 5). The radius of octahedral space is expanded from 0.517 to $0.524 \AA$ (Fig. 1a) calculated by using the aforementioned equation.

Previous studies based on $\mathrm{Ni}-\mathrm{ZnO}$ system have revealed that the formation of $\mathrm{Ni}-\mathrm{Zn}$ alloy does not change the electronic structure of $\mathrm{Ni}$ much $^{31}$. In addition, theoretical calculation exhibits that there is little hybridization between $\mathrm{Ni} 3 d$ and $\mathrm{Zn} 3 d$ states in $\mathrm{Ni}_{3} \mathrm{Zn}^{30}$. Thus, it seems that the electronic structure and the capability to dissociate hydrocarbon molecules of $\mathrm{Ni}$ have merely altered in $\mathrm{Ni}_{3} \mathrm{Zn}$ structure, as it is the initial step to form the interstitial carbon structure. Therefore, temperature-programmed surface reaction (TPSR) experiments were conducted to determine the dissociation temperature of acetylene on the surface of $\mathrm{Ni}$ and $\mathrm{Ni}_{3} \mathrm{Zn}$. Acetylene was adopted in that it is the most reactive carbon source due to its highest change of Gibbs free energy in forming metal carbide structure ${ }^{34}$. The results in Fig. 1 b, $c$ exhibit that $\mathrm{Ni}_{3} \mathrm{Zn}$ structure maintain the 
a
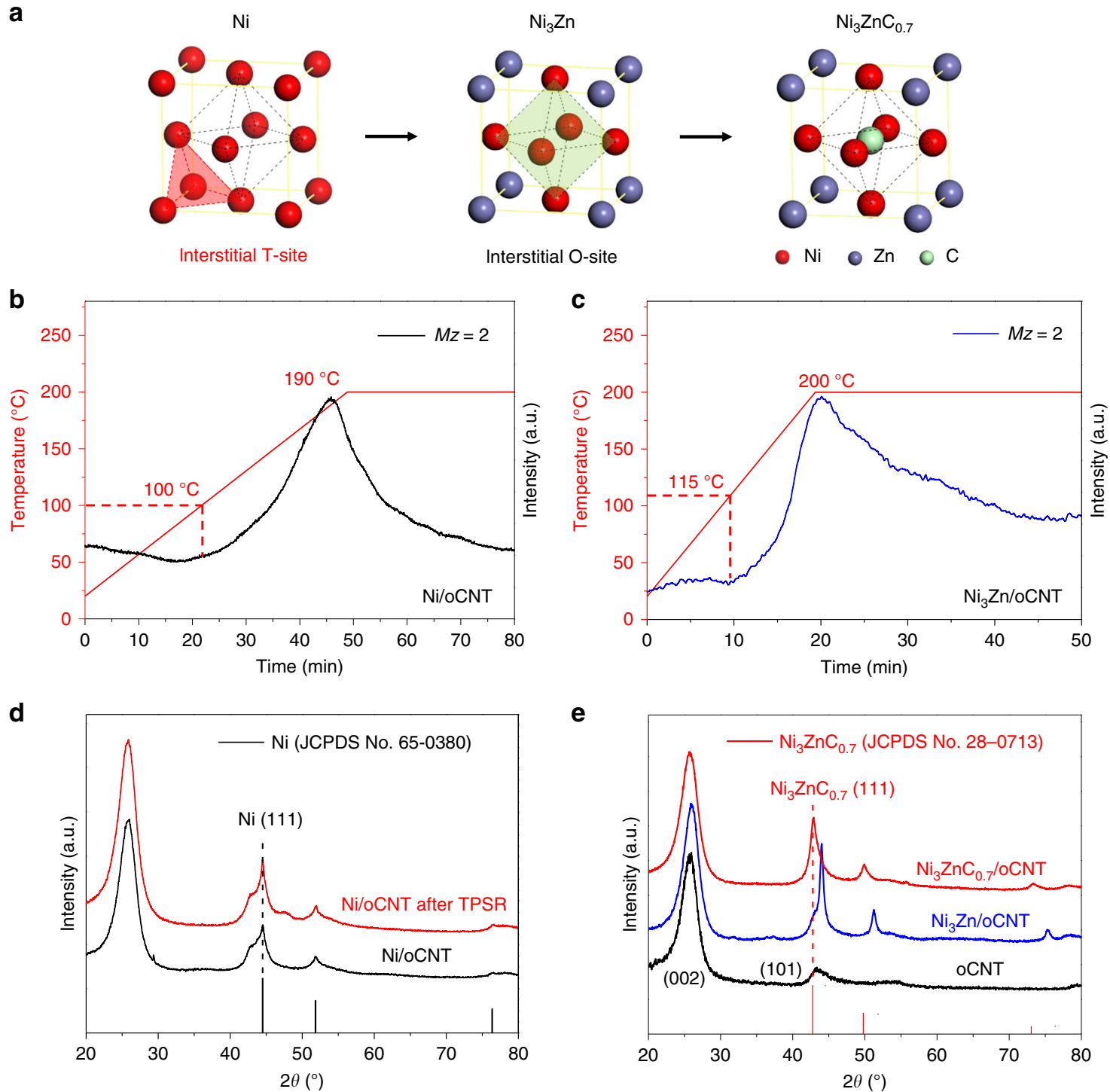

e

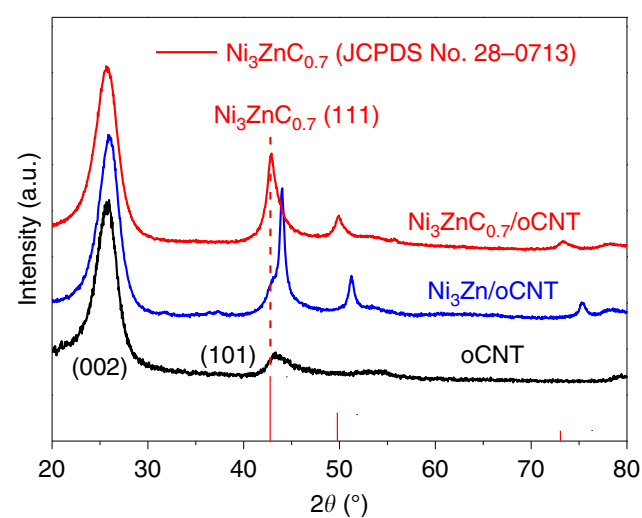

Fig. 1 Incorporation of carbon atom in $\mathbf{N i}_{3} \mathbf{Z n}$. a Schematic of expanded interstitial sites in the unit cells of $\mathrm{Ni}_{1} \mathrm{Ni}_{3} \mathrm{Zn}$, and $\mathrm{Ni}_{3} \mathrm{ZnC} \mathrm{C}_{0.7}$. The red and black dash lines indicate the tetragonal and octahedral interstitial sites. TPSR-MS results of $\mathrm{Ni} / \mathrm{oCNT}(\mathbf{b})$ and $\mathrm{Ni}_{3} \mathrm{Zn} / \mathrm{oCNT}$ (c) at elevated temperatures under 1.0 vol $\% \mathrm{C}_{2} \mathrm{H}_{2} / \mathrm{He}$ atmosphere. XRD patterns of $\mathrm{Ni} / \mathrm{oCNT}(\mathbf{d})$ and $\mathrm{Ni}_{3} \mathrm{Zn} / \mathrm{oCNT}$ (e) after reduction and acetylene treatment.

strong capability to dissociate acetylene with an only $15^{\circ} \mathrm{C}$ delay compared to $\mathrm{Ni}$. Although $\mathrm{Ni}$ exhibits the strong capability to dissociate acetylene, the XRD results (Fig. 1d) revealed that the $\mathrm{Ni}$ NPs maintained in the FCC structure after 1.0 vol\% $\mathrm{C}_{2} \mathrm{H}_{2} / \mathrm{He}$ treatment until $500{ }^{\circ} \mathrm{C}$. The dissociated carbon atoms tend to segregate from the Ni NPs and form graphitic layers or even CNTs/CNFs instead of the stable carbides. It has been observed that instead of $\mathrm{Ni}$ carbide formation, it is carbon encapsulation that prefers to occur to Ni carbide formation in Ni NPs supported on oxidized CNTs (Ni/oCNTs). TEM investigations confirm the encapsulation of graphitic layers on the FCC Ni NPs (Supplementary Fig. 6). The morphology of Ni NPs is greatly changed after the acetylene treatment, which is well consistent with the reported dynamic behavior and elongation of Ni NPs during CNT growth ${ }^{35}$. $\mathrm{Ni}_{3} \mathrm{Zn}$ exhibits a slightly reduced capability to dissociate acetylene in comparison with $\mathrm{Ni}$. Interestingly, the carbon atom could readily dissolve and diffuse in $\mathrm{Ni}_{3} \mathrm{Zn}$ and form the $\mathrm{Ni}_{3} \mathrm{ZnC}_{0.7}$ structure at low temperature under 1.0 vol\% $\mathrm{C}_{2} \mathrm{H}_{2} /$ $\mathrm{He}$ atmosphere. The lattice parameter of $\mathrm{Ni}_{3} \mathrm{Zn}$ is further enlarged with the carbon inclusion. As indicated by the diffraction peaks in XRD patterns (Fig. 1e), they shift left and also consistent well with $\mathrm{Ni}_{3} \mathrm{ZnC}_{0.7}$ structure $(a=b=c=3.66 \AA$, JCPDS No. 28-0713).

Microstructural clarification of $\mathrm{Ni}_{3} \mathrm{Zn}$ and $\mathrm{Ni}_{3} \mathrm{ZnC}_{0.7}$. The crystal structures of $\mathrm{Ni}_{3} \mathrm{Zn}$ alloy were identified through XRD measurements: it has the expanded interstitial sites and the generated $\mathrm{Ni}_{3} \mathrm{ZnC}_{0.7}$ structure with carbon incorporation. Following the microstructural features before and after carbon atom inclusion, an aberration-corrected TEM equipped with energydispersive X-ray spectroscopy (EDX) elemental analysis and electron energy loss spectroscopy (EELS) is applied. Firstly, highangle annular dark-field scanning transmission electron microscopy (HAADF-STEM) images demonstrate the morphology of the catalysts. As shown in Fig. $2 \mathrm{a}$, the formed $\mathrm{Ni}_{3} \mathrm{Zn}$ NPs are uniformly distributed on oCNT and exhibit an average particle size of $9.1 \pm 1.8 \mathrm{~nm}$. Through the dissociation of adsorbed acetylene and the dissolution of carbon atoms in the $\mathrm{Ni}_{3} \mathrm{Zn}$ structure, the particle size of $\mathrm{Ni}_{3} \mathrm{ZnC}_{0.7} \mathrm{NPs}$ increased slightly $(9.8 \pm 2.9 \mathrm{~nm})$ (Fig. 2b). High-resolution TEM images and corresponding fast Fourier transform (FFT) (Fig. 2c, d) demonstrate the single crystalline nature of NPs in both pristine $\mathrm{Ni}_{3} \mathrm{Zn}$ and $\mathrm{Ni}_{3} \mathrm{ZnC}_{0.7}$. 

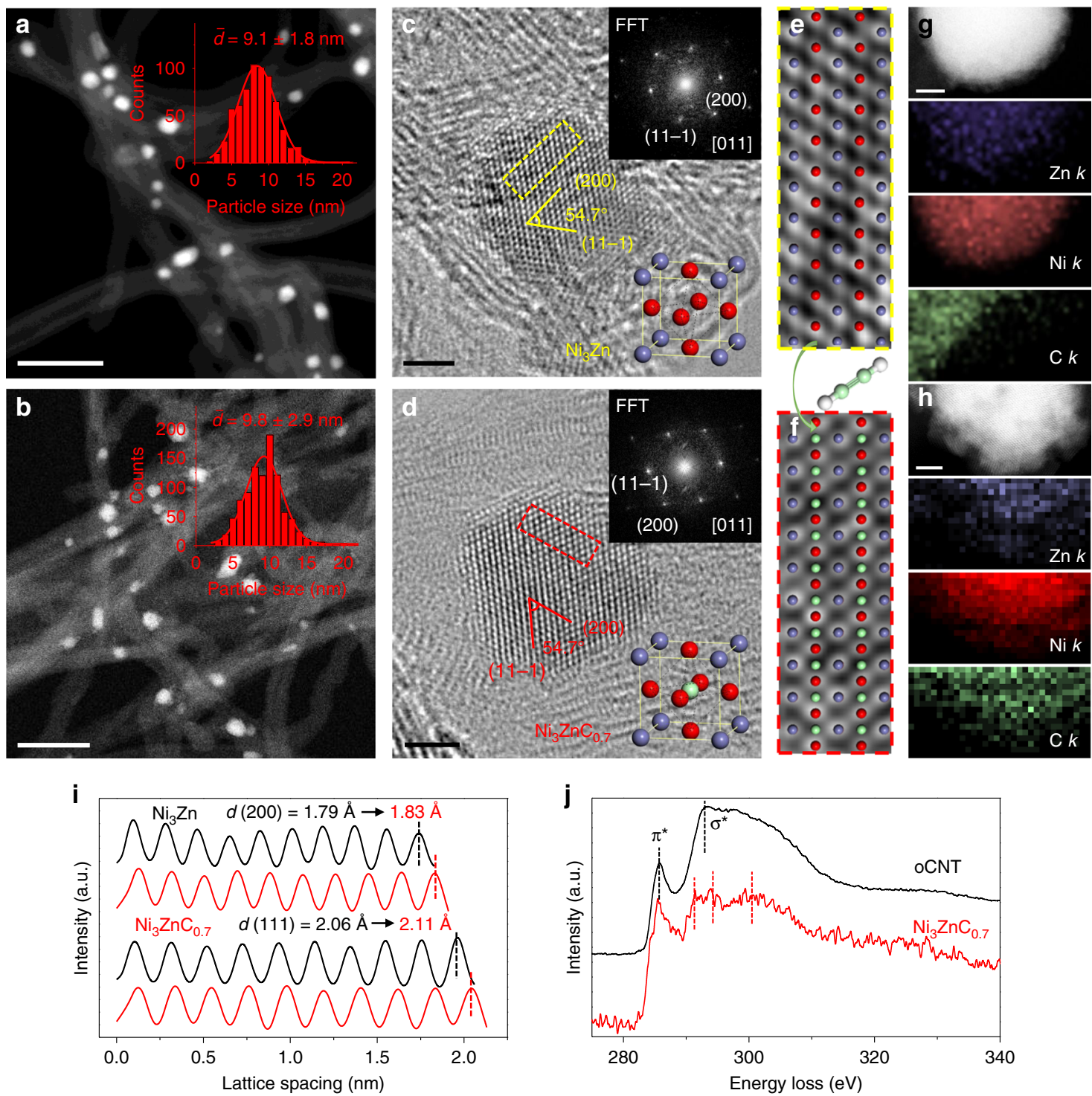

Fig. 2 Microstructural characterization of $\mathbf{N i}_{\mathbf{3}} \mathbf{Z n}$ and $\mathbf{N i}_{\mathbf{3}} \mathbf{Z n C} \mathbf{C}_{\mathbf{0 . 7}}$. STEM images of $\mathrm{Ni}_{3} \mathrm{Zn} / \mathrm{oCNT}(\mathbf{a})$ and $\mathrm{Ni}_{3} \mathrm{ZnC} \mathrm{C}_{0.7} / \mathrm{oCNT}(\mathbf{b})$, the right-top insets are the corresponding particle size distribution diagrams. HRTEM images of $\mathrm{Ni}_{3} \mathrm{Zn}(\mathbf{c})$ and $\mathrm{Ni}_{3} \mathrm{ZnC}_{0.7}$ (d). The top-right and bottom-right insets correspond to the FFTs and unit cells. e-f The atomic model overlapped with the HRTEM images acquired from the dashed box in $\mathbf{c}$, d. High-resolution STEM images of Ni $\mathrm{Z}_{3} \mathrm{n}$ (g) and $\mathrm{Ni}_{3} \mathrm{ZnC}_{0.7}(\mathbf{h})$ with the corresponding EDX elemental mapping of $\mathrm{Ni}$ (red), $\mathrm{Zn}$ (purple), and $\mathrm{C}$ (green). $\mathbf{i}$ The integrated intensities of $\mathrm{Ni}_{3} \mathrm{Zn}$ and $\mathrm{Ni}_{3} \mathrm{ZnC}_{0.7}$ perpendicular to the (11-1) and (200) planes. $\mathbf{j}$ C K-edge EEL spectra of oCNT and $\mathrm{Ni}_{3} \mathrm{ZnC} \mathrm{C}_{0.7}$. Scale bars: $50 \mathrm{~nm}$ in $\mathbf{a}, \mathbf{b}$ and $2 \mathrm{~nm}$ in $\mathbf{c}, \mathbf{d}, \mathbf{g}, \mathbf{h}$

For the characteristic angles of FCC metals, both of which have an acute angle of $54.7^{\circ}$ between (200) and (11-1) lattice planes (also illustrated by Fig. 2c, d). An obvious difference in terms of crystal structure lies at the expanded lattice parameters of $\mathrm{Ni}_{3} \mathrm{ZnC}_{0.7}$ after the incorporation of carbon atoms into $\mathrm{Ni}_{3} \mathrm{Zn}$ as evidenced by the aforementioned XRD results. Thus, the spacings of the lattice fringes are compared for (111) and (200) planes of both $\mathrm{Ni}_{3} \mathrm{Zn}$ and $\mathrm{Ni}_{3} \mathrm{ZnC}_{0.7}$ (Fig. 2e, f) collected from either [011] (Fig. 2c, d) or [001] (Supplementary Fig. 7) directions, respectively. The integrated pixel intensities are measured on the basis of the average lattice spacing over ten atomic layers (Fig. 2i). As a result, the average pristine $\mathrm{Ni}_{3} \mathrm{Zn}$ (111) spacing is measured as $2.06 \AA$, which is consistent with previously reported calculations for $\mathrm{Ni}_{3} \mathrm{Zn}^{29,30}$. The intensity profile of the $\mathrm{Ni}_{3} \mathrm{ZnC}_{0.7}$ atomic layers indicates a larger spacing $(2.11 \AA)$ compared with the pristine $\mathrm{Ni}_{3} \mathrm{Zn}$. Similar integrated pixel intensities are determined for the average lattice spacing of (200) from the [001] direction. To further prove the successful incorporation of the interstitial carbon atoms into $\mathrm{Ni}_{3} \mathrm{Zn}$, the EDX elemental maps are conducted to provide composition and elemental distribution information. Both $\mathrm{Ni}$ (K-edge) and $\mathrm{Zn}$ (K-edge) elemental maps of $\mathrm{Ni}_{3} \mathrm{Zn}$ and $\mathrm{Ni}_{3} \mathrm{ZnC}_{0.7} \mathrm{NPs}$ are well consistent with the outlines of STEM images (Fig. 2g, h). That is to say, a homogeneous distribution of $\mathrm{Ni}$ and $\mathrm{Zn}$ existed. Carbon (K-edge) EDX maps in Fig. $2 \mathrm{~h}$ reveal the existence and uniform distribution of $\mathrm{C}$ in $\mathrm{Ni}_{3} \mathrm{ZnC}_{0.7} \mathrm{NPs}$. It is different from $\mathrm{Ni}_{3} \mathrm{Zn}$ structure (Fig. $2 \mathrm{~g}$ ), and explicitly evidence the incorporation of carbon atom after acetylene treatment. The proportions of the atomic ratio in the $\mathrm{Ni}_{3} \mathrm{ZnC}_{0.7} \mathrm{NPs}$ are also confirmed via EDX line scan analysis (Supplementary Fig. 8). Subsequently, the body-centered carbon atom is identified by using EELS. The carbon K-edge EEL spectrum of $\mathrm{Ni}_{3} \mathrm{ZnC}_{0.7}$ (Fig. 2j) exhibits three peaks in a range from 290 to $300 \mathrm{eV}(291$, 294 , and $300 \mathrm{eV}$ ). Thus, it reveals a unique coordination structure of carbon atom and distinct from the $s p^{2}$ structure of carbon in the oCNTs. EELS signal of carbon is not found for $\mathrm{Ni}_{3} \mathrm{Zn} \mathrm{NP}$ (Supplementary Fig. 9), which is consistent with the EDX results. 
Catalytic performance in acetylene hydrogenation. Microscopic and spectroscopic results explicitly demonstrate that carbon atoms penetrate and occupy the interstitial site of $\mathrm{Ni}_{3} \mathrm{Zn}$. It is supposed to inhibit the hydrogenation pathway of interstitial hydrogen and increase the selectivity towards ethylene. Thus, the selectivity is detected toward ethylene in acetylene hydrogenation pathway. Meanwhile, the phase transition process from $\mathrm{Ni}_{3} \mathrm{Zn}$ to $\mathrm{Ni}_{3} \mathrm{ZnC}_{0.7}$ is monitored via an in situ XRD experiment (Fig. 3a) under a 1.0 vol\% $\mathrm{C}_{2} \mathrm{H}_{2} / \mathrm{He}$ atmosphere. As shown in Fig. 3a, the diffraction peaks of the $\mathrm{Ni}_{3} \mathrm{Zn}$ (111) and (200) planes decreased gradually, whereas the intensity of $\mathrm{Ni}_{3} \mathrm{ZnC}_{0.7}$ (111) and (200) peaks increased until a complete transformation of $\mathrm{Ni}_{3} \mathrm{Zn}$ to $\mathrm{Ni}_{3} \mathrm{ZnC}_{0.7}$ occurred with a temperature preservation at $200^{\circ} \mathrm{C}$ during $1 \mathrm{~h}$. During the subsurface structure changed from hydrogen to carbon atoms, the selectivity towards ethylene increased highly from $30.6 \%$ to $94.5 \%$ (Fig. 3b), while the conversion of acetylene decreased from $99.2 \%$ to $56.3 \%$. In general, the intermediate interstitial structure is metastable and depend kinetically on the chemical potential of desired elements ${ }^{14}$. Herein, the $\mathrm{Ni}_{3} \mathrm{ZnC}_{0.7} / \mathrm{oCNT}$ catalyst exhibits a superior and stable selectivity for a variety of $\mathrm{H}_{2} / \mathrm{C}_{2} \mathrm{H}_{2}$ ratios (Fig. $3 \mathrm{c}$ ) due to the removal of the subsurface interstitial $\mathrm{H}$ hydrogenation pathway, which was evidenced by a series of $\mathrm{H}_{2}$ temperatureprogrammed desorption experiments of $\mathrm{Ni} / \mathrm{oCNT}, \mathrm{Ni}_{3} \mathrm{Zn} / \mathrm{oCNT}$, and $\mathrm{Ni}_{3} \mathrm{ZnC}_{0.7} / \mathrm{oCNT}$ catalysts (Supplementary Fig. 10). For a ratio in the range of $3-15, \mathrm{Ni}_{3} \mathrm{ZnC}_{0.7} / \mathrm{oCNT}$ yields a $99.9-86.1 \%$ selectivity towards ethylene, and a $0.1-13.9 \%$ selectivity towards

a
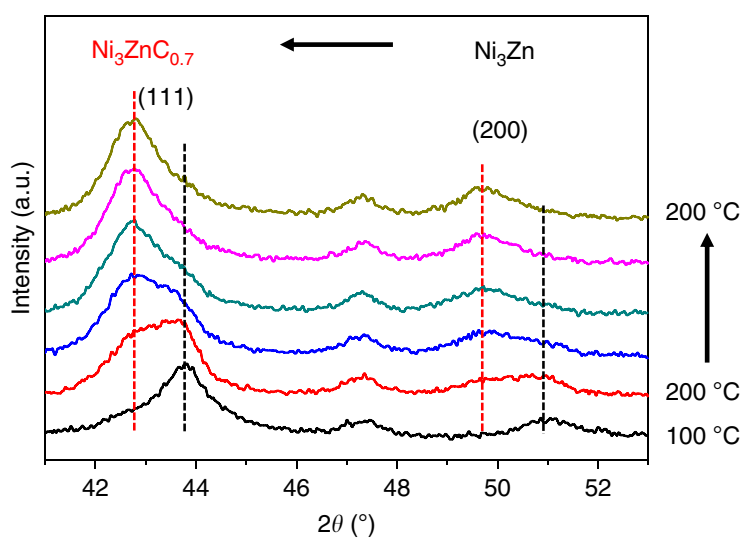

b

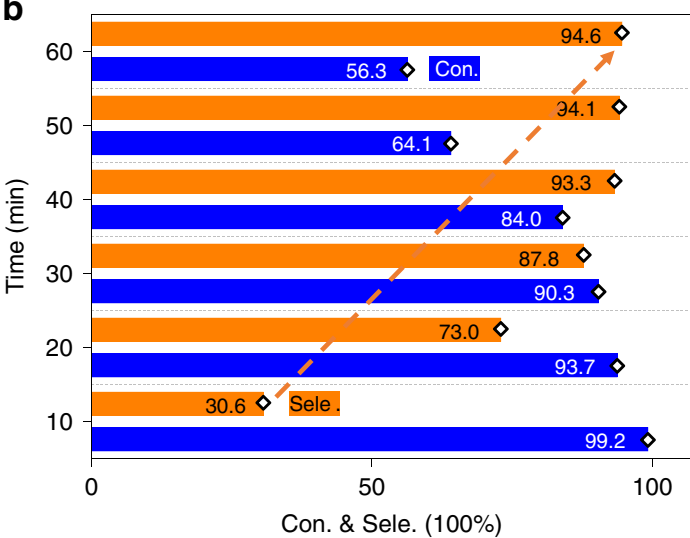

ethane in the conversion range of 9.7-93.5\%. Generally, the reaction probabilities between adsorbed $\mathrm{H}$ and intermediate ethylene would increase as the coverage of activated $\mathrm{H}$ increases with the $\mathrm{H}_{2}$ concentration. Also, it is the highly exothermic feature of ethylene hydrogenation that leads further to the increase of ethane selectivity and uncontrollable temperature runaway ${ }^{13,36}$. Therefore, the high selectivity of the $\mathrm{Ni}_{3} \mathrm{ZnC}_{0.7}$ catalyst within a wide $\mathrm{H}_{2} / \mathrm{C}_{2} \mathrm{H}_{2}$ ratio range is industrially important, which allows for stable operation under fluctuated conditions. In addition, the selectivity control under a constant high conversion is challenging but desirable to eliminate the trace amount acetylene in ethylene. As shown in Fig. 3d, the obtained $\mathrm{Ni}_{3} \mathrm{ZnC}_{0.7} / \mathrm{oCNT}$ catalyst exhibits $94 \%$ selectivity toward ethylene under $99 \%$ conversion in a 720 min reaction, which is superior to $\mathrm{Ni} /$ oCNT catalyst (27\% selectivity at the initial $99 \%$ conversion). The Ni/oCNT catalyst exhibits a rapidly reduced activity and poor stability under reaction conditions. This is supposed to the segregation and accumulation of carbonaceous fragments on the $\mathrm{Ni}$ surface and consistent with previous studies ${ }^{17,37-39}$. Obviously, the decreased conversion of alkyne for $\mathrm{Ni}$ catalyst cannot meet the industrial requirements and may poison the following polymerization catalysts. However, the $\mathrm{Ni}_{3} \mathrm{ZnC}_{0.7} /$ oCNT catalyst exhibits excellent stability in comparison with $\mathrm{Ni}$. That is, the introduction of carbon atoms not only inhibits the unselective hydrogenation pathway but also regulates the electronic structure of $\mathrm{Ni}$. Therefore, it suppresses the further dissociation of adsorbed acetylene molecules. Thus, the stability
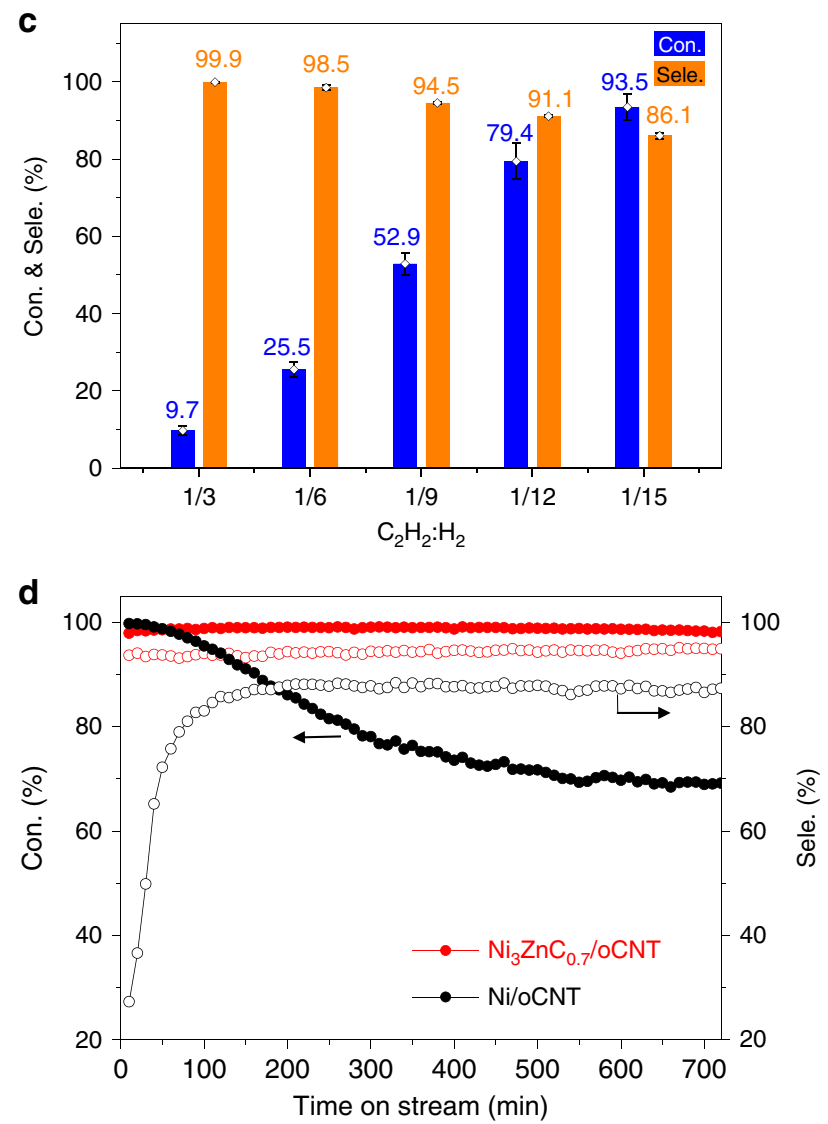

Fig. 3 Catalytic performance in acetylene selective hydrogenation reaction. $\mathbf{a}$ In situ $\mathrm{XRD}$ patterns of the structural evolution from $\mathrm{Ni}_{3} \mathrm{Zn}$ to $\mathrm{Ni}_{3} \mathrm{ZnC} \mathrm{C}_{0.7}$ (black curve: $100^{\circ} \mathrm{C}$, other curves: $200^{\circ} \mathrm{C}$ with prolonged times) under a 1.0 vol\% $\mathrm{C}_{2} \mathrm{H}_{2} /$ He atmosphere. b The reactivity corresponds to the structural evolution of $\mathrm{Ni}_{3} \mathrm{Zn} / \mathrm{oCNT}$ catalyst under reaction conditions. c Conversion and selectivity of $\mathrm{Ni}_{3} \mathrm{ZnC}_{0.7} /$ oCNT catalyst (5.0 mg) under various acetylene to hydrogen ratios. Error bars represent standard deviation of experimental data acquired from three times. d Stability test $\left(4.5\right.$ vol\% $\mathrm{H}_{2}, 20.0$ vol\% $\mathrm{C}_{2} \mathrm{H}_{4}, 0.5$ vol\% $\mathrm{C}_{2} \mathrm{H}_{2}$, helium as balance) of $\mathrm{Ni} / \mathrm{oCNT}(15.0 \mathrm{mg})$ and $\mathrm{Ni}_{3} \mathrm{ZnC} \mathrm{C}_{0.7} / \mathrm{oCNT}(10.0 \mathrm{mg})$ catalysts. The solid and hollow symbols represent the acetylene conversion and the selectivity to ethylene. 
of $\mathrm{Ni}_{3} \mathrm{ZnC}_{0.7} / \mathrm{oCNT}$ catalyst is significantly improved in comparison with Ni (Supplementary Fig. 11). The reaction carbon balance of $\mathrm{Ni}_{3} \mathrm{ZnC}_{0.7} / \mathrm{oCNT}$ catalyst was evaluated in the absence of ethylene. As shown in Supplementary Fig. 12, the $\mathrm{Ni}_{3} \mathrm{ZnC}_{0.7} /$ oCNT catalyst exhibits good stability and improved selectivity compared with ethylene-rich condition during $13 \mathrm{~h}$ reaction. The carbon balance is almost $100 \%$ during the test. In addition, the noble metal-based Pd/oCNT and PdAg/oCNT catalysts synthesized via the same impregnation method (Supplementary Figs. 13 and 14) are also compared with the $\mathrm{Ni}_{3} \mathrm{ZnC}_{0.7} / \mathrm{oCNT}$. Both the carbon-based support and the addition of $\mathrm{Ag}$ led to a selectivity enhancement in this reaction as previously reported ${ }^{40,41}$. Because of carbonaceous deposition during the reaction, the Pd (97-70\%) and PdAg (93-57\%) catalysts showed poor stability (Supplementary Figs. 15 and 16) compared with $\mathrm{Ni}_{3} \mathrm{ZnC}_{0.7}{ }^{42-44}$. The thermogravimetric analysis (TGA) experiments were conducted to evaluate the carbon deposition on the spent $\mathrm{Ni}_{3} \mathrm{Zn} / \mathrm{oCNT}$ and $\mathrm{Ni}_{3} \mathrm{ZnC}_{0.7} / \mathrm{oCNT}$ catalysts. As shown in Supplementary Fig. 17, the fresh and spent $\mathrm{Ni}_{3} \mathrm{ZnC}_{0.7} / \mathrm{oCNT}$ catalysts exhibit a similar initial weight loss at $395^{\circ} \mathrm{C}$, which is supposed to the combustion of oCNT. The weight loss occurs at $240{ }^{\circ} \mathrm{C}$ of the spent $\mathrm{Ni}_{3} \mathrm{Zn} /$ oCNT, however, which is much lower than that of fresh $\mathrm{Ni}_{3} \mathrm{Zn} /$ oCNT. It indicates the strongly adsorbed carbonaceous deposition on the surface of $\mathrm{Ni}_{3} \mathrm{Zn}$ after $10 \mathrm{~h}$ reaction at $100^{\circ} \mathrm{C}$. These TGA results further prove that the carbonaceous accumulation is highly suppressed on the surface of $\mathrm{Ni}_{3} \mathrm{ZnC}_{0.7} / \mathrm{oCNT}$ catalysts. These results indicate that the introduction of carbon atoms to the interstitial sites of $\mathrm{Ni}$ enables an efficient suppression of the over-hydrogenation reaction pathway and the carbonaceous accumulation on the surface (Supplementary Fig. 18). As a result, it affords the $\mathrm{Ni}_{3} \mathrm{ZnC}_{0.7} / \mathrm{oCNT}$ with high activity and selectivity, i.e., a stable catalyst in acetylene hydrogenation reaction. In addition, the selectivity control in acetylene hydrogenation is more challenging under high-pressure condition, which should be carefully taken into account ${ }^{45,46}$.

Electronic properties of $\mathrm{Ni}$ with $\mathrm{Zn}$ and $\mathrm{C}$ atom inclusion. The variation of the electronic structure of $\mathrm{Ni}$ caused by the charge transfer between $\mathrm{C}$ and $\mathrm{Ni}$ in $\mathrm{Ni}_{3} \mathrm{ZnC}_{0.7}$ is demonstrated in Fig. 4. After calibration with reference samples ( $\mathrm{Ni}$ foil and $\mathrm{Ni}$ oxide), the X-ray absorption near edge structure (XANES) spectra of the $\mathrm{Ni}$ K-edge were conducted for the $\mathrm{Ni}_{3} \mathrm{Zn} / \mathrm{oCNT}$ and $\mathrm{Ni}_{3} \mathrm{ZnC}_{0.7} /$ oCNT catalysts. It clearly shows that $\mathrm{Ni}$ is indeed electrondeficient in $\mathrm{Ni}_{3} \mathrm{ZnC}_{0.7}$ compared with $\mathrm{Ni}$ and $\mathrm{Ni}_{3} \mathrm{Zn}$ (Fig. 4a). Furthermore, in situ XANES experiments reveal the evolution of the electronic structure of $\mathrm{Ni}$ from $\mathrm{Ni}_{3} \mathrm{Zn}$ to $\mathrm{Ni}_{3} \mathrm{ZnC}_{0.7}$. The intensity of the white line (Fig. $4 \mathrm{~b}$ ) increases from $\mathrm{Ni}_{3} \mathrm{Zn}$ gradually to $\mathrm{Ni}_{3} \mathrm{ZnC}_{0.7}$, which suggests $\mathrm{Ni}$ electron deficiency with the incorporation of carbon. The charge transfer distribution maps (Fig. 4c) acquired from the density functional theory (DFT) calculations ${ }^{47}$ was applied. It clearly displays the charge density differences in $\mathrm{Ni}_{3} \mathrm{Zn}$ and $\mathrm{Ni}_{3} \mathrm{ZnC}_{0.7}$ along the [100] and [110] directions, respectively. In $\mathrm{Ni}_{3} \mathrm{Zn}$, a charge transfer occurs from $\mathrm{Zn}$ to $\mathrm{Ni}$ because of the electronegativity differences between $\mathrm{Ni}$ (1.88) and $\mathrm{Zn}$ (1.66). As a result, $\mathrm{Ni}$ has an electron richness of 0.138 per atom. After $\mathrm{C}$ incorporation, an obvious charge transfer occurs from $\mathrm{Ni}$ to $\mathrm{C}$, rendering $\mathrm{Ni}$ with an electron deficiency of -0.133 per atom (Fig. 4d). Since the interaction is negligible between $\mathrm{Zn}$ and $\mathrm{C}$ (Fig. 4c), there is no charge transfer in this case. Therefore, the positive charge and the lower d-band center (Supplementary Fig. 19) of $\mathrm{Ni}$ in $\mathrm{Ni}_{3} \mathrm{ZnC}_{0.7}$ suppresses the dissociation of acetylene and weakens the adsorption of acetylene/ ethylene, which contributes to the decreased polymerization products. In short, it leads to improved stability for highly efficient acetylene hydrogenation.

\section{Discussion}

This work demonstrates that highly efficient hydrogenation of alkyne could be obtained via introducing carbon atoms within $\mathrm{Ni}$ lattice containing an expanded interstitial space. With an addition of $25 \% \mathrm{Zn}$, the interstitial space of $\mathrm{Ni}$ is expanded with a wellmaintained capability to adsorb and dissociate hydrocarbon molecules. Thus, the dissociated carbon atoms enable readily penetrating into $\mathrm{Ni}_{3} \mathrm{Zn}$ to offer the formation of $\mathrm{Ni}_{3} \mathrm{ZnC}_{0.7}$ structure under acetylene contained atmosphere at $200^{\circ} \mathrm{C}$. Both XRD and TEM investigations confirm the lattice parameter expansion after the inclusion of $\mathrm{Zn}$ and carbon. EDX and EELS analysis explicitly reveal the existence of carbon in $\mathrm{Ni}_{3} \mathrm{ZnC}_{0.7}$. Combined with in situ XANES experiments and DFT calculations, the introduced carbon atoms coordinate with the neighboring $\mathrm{Ni}$ atoms and impair a positive charge to Ni. As a result, the interstitial occupation in $\mathrm{Ni}_{3} \mathrm{ZnC}_{0.7}$ suppresses the reaction pathway of ethylene hydrogenation and increases the selectivity drastically under hydrogen-rich/poor conditions. That is to say, it can effectively bypass the temporal metastable state variation under a fluctuation reaction condition. More importantly, the formed $\mathrm{Ni}_{3} \mathrm{ZnC}_{0.7}$ exhibits a highly improved stability compared with $\mathrm{Ni}$. As a result, the dissociation and accumulation of carbonaceous species are inhibited on the surface. Hence, our work provides a proof-of-concept to control of interstitial sites in heterogeneous metal catalyst. Moreover, such a new solution enables improving the selectivity and stability for selective acetylene hydrogenation.

\section{Methods}

Catalysts preparation. The multiwall CNTs was purchased from Shandong Dazhan Nano Materials Co., Ltd, China. The CNTs were firstly treated with $\mathrm{HCl}$ and then oxidized with concentrated $\mathrm{HNO}_{3}$ at $140{ }^{\circ} \mathrm{C}$ for $2 \mathrm{~h}$ (oCNT). The $\mathrm{Ni}_{3} \mathrm{Zn} /$ oCNT catalyst was synthesized with a typical impregnation method. For the $5.0 \mathrm{wt}$ $\% \mathrm{Ni}_{3} \mathrm{Zn} / \mathrm{oCNT}, 101 \mathrm{mg} \mathrm{Ni}\left(\mathrm{NO}_{3}\right)_{2}$ and $33.7 \mathrm{mg} \mathrm{Zn}\left(\mathrm{NO}_{3}\right)_{2}$ were dissolved in $40 \mathrm{~mL}$ ethanol, then $374 \mathrm{mg}$ oCNT was added into the solution and the suspension was ultrasonic dispersed for $1 \mathrm{~h}$ to obtain a homogeneous distribution. The ethanol was evaporated at $50^{\circ} \mathrm{C}$ using a rotary evaporator. After calcination at $100{ }^{\circ} \mathrm{C}$ for $2 \mathrm{~h}$ in static air, the reduction process was conducted at elevated temperature with a heating rate of $10^{\circ} \mathrm{C} \mathrm{min}{ }^{-1}$ from 30 to $500{ }^{\circ} \mathrm{C}$ for $2 \mathrm{~h}$ in $50.0 \mathrm{vol} \% \mathrm{H}_{2}$ in Ar with the flow rate of $100 \mathrm{~mL} \mathrm{~min}^{-1}$. The $\mathrm{Ni}_{3} \mathrm{Zn} / \mathrm{oCNT}$ catalyst was obtained after cooling to room temperature. The $\mathrm{Ni}_{3} \mathrm{ZnC}_{0.7} / \mathrm{oCNT}$ catalyst prepared by switching the gas atmosphere to $1.0 \mathrm{vol} \% \mathrm{C}_{2} \mathrm{H}_{2} / \mathrm{He}$ at $200{ }^{\circ} \mathrm{C}$ for $1 \mathrm{~h}$ after the reduction of $\mathrm{Ni}_{3} \mathrm{Zn} / \mathrm{oCNT}$. The $5.0 \mathrm{wt} \% \mathrm{Ni} / \mathrm{oCNT}, 2.0 \mathrm{wt} \% \mathrm{Pd} / \mathrm{oCNT}$ and $\mathrm{PdAg} / \mathrm{oCNT}$ catalysts were also synthesized with the same impregnation method and reduced at $500{ }^{\circ} \mathrm{C}$.

XRD investigations. The in situ XRD measurements were conducted on a PANalytical X'pert PRO diffractometer with XRK900 in situ chamber using CuKa radiation, operated at $40 \mathrm{kV}$ and $30 \mathrm{~mA}$. The $10.0 \mathrm{wt} \%$ loading of $\mathrm{Ni}$ and $\mathrm{Zn}$ on oCNT was chosen for a clear peak evolution considering that $5.0 \mathrm{wt} \%$ loading sample would cause low intensity of the diffraction peaks and lead to ambiguity in peak recognition in the in situ XRD experiments. The $10.0 \mathrm{wt} \% \mathrm{Ni}_{3} \mathrm{Zn} / \mathrm{oCNT}$ sample was transferred to an in situ chamber with the beryllium window. Then the $\mathrm{H}_{2} / \mathrm{He}$ flow at $10 \mathrm{~mL} \mathrm{~min}^{-1}$ was introduced after the He flushing, the temperature elevated with a rate of $10^{\circ} \mathrm{C} \mathrm{min}{ }^{-1}$ from room temperature to $500{ }^{\circ} \mathrm{C}$ while the flow is steady. The XRD patterns were recorded at desired temperatures from $10^{\circ}$ to $90^{\circ}$. After the reduction, the chamber was cooled down to room temperature and flushed with helium. Then the acetylene was imported and the evolution of the $\mathrm{Ni}_{3} \mathrm{Zn}$ structure to $\mathrm{Ni}_{3} \mathrm{ZnC}$ structure was examined at elevated temperature to $200{ }^{\circ} \mathrm{C}$ under 1.0 vol\% $\mathrm{C}_{2} \mathrm{H}_{2} / \mathrm{He}$ flow $\left(10 \mathrm{~mL} \mathrm{~min}^{-1}\right)$. The ex situ XRD patterns were performed on a Rigaku D/max 2400 diffractometer (CuKa radiation, $\lambda=$ $0.15418 \mathrm{~nm})$.

X-ray absorption spectroscopy investigation. The Ni K-edge XANES experiments were performed at the beamline 1W1B of the Beijing Synchrotron Radiation Facility, Institute of High Energy Physics, Chinese Academy of Sciences. The electron storage ring was operated at $2.5 \mathrm{GeV}$. Using a $\mathrm{Si}(111)$ double-crystal monochromator; all the data collections were carried out in the transmission mode for the Ni K-edge. A Ni foil was measured simultaneously and used for the energy calibration. The XAS data analysis was carried out with the programs of IFEFFIT. In situ Ni K-edge XANES spectra of $\mathrm{Ni}_{3} \mathrm{Zn} / \mathrm{oCNT}$ catalyst were carried out in an in situ reaction cell. The powdered sample was pressed into sheet and loaded into a reactor cell equipped with polyimide windows. Then, the sample was reduced in $50.0 \mathrm{vol} \% \mathrm{H}_{2} / \mathrm{He}$ at $500{ }^{\circ} \mathrm{C}$ for $1 \mathrm{~h}$ at a heating rate of $10^{\circ} \mathrm{C} \mathrm{min}-1$, and 

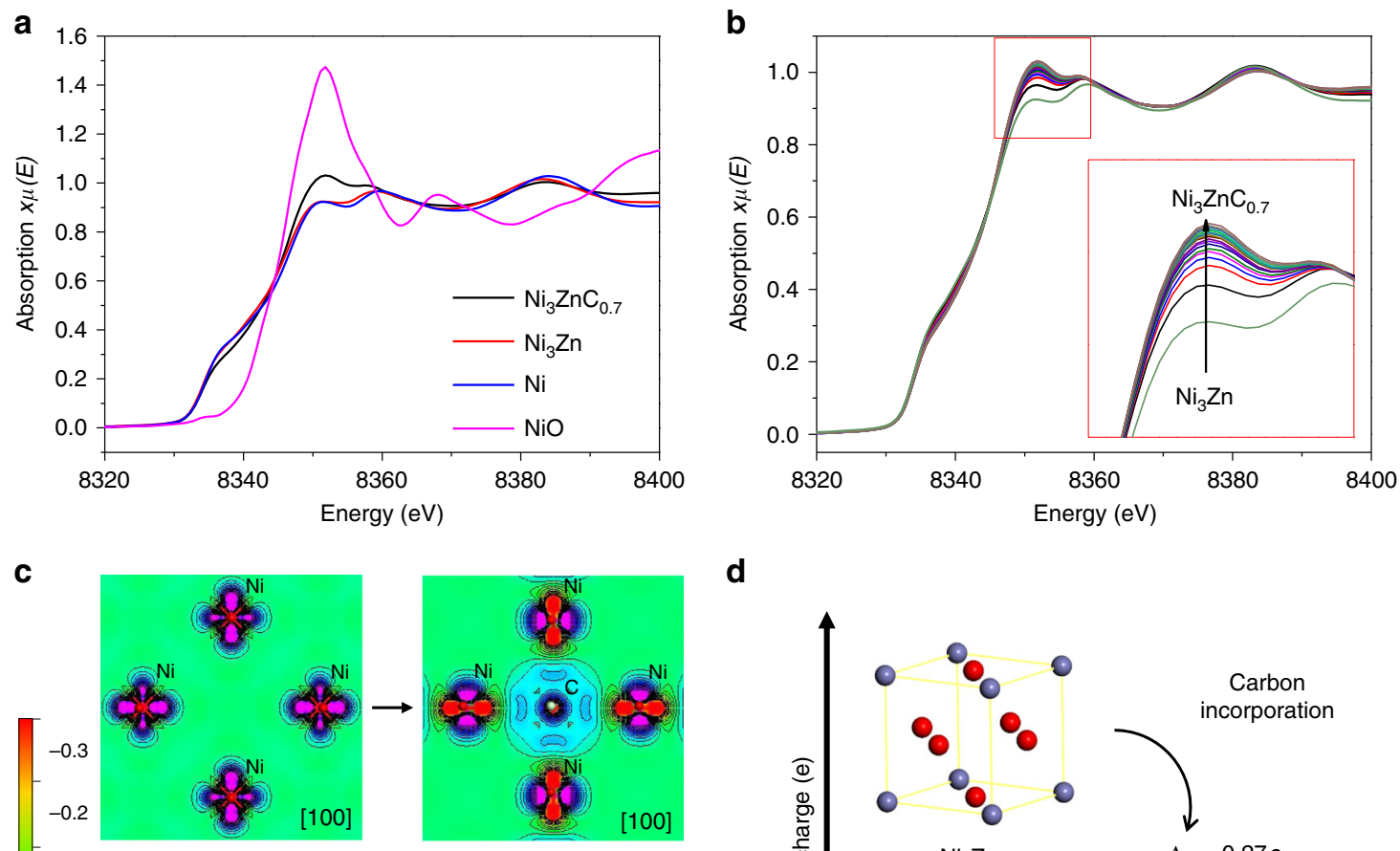

d

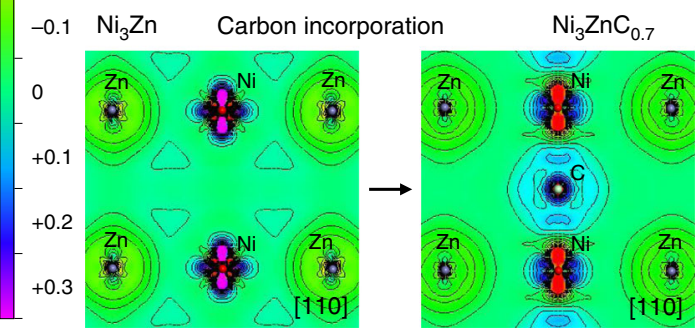

Charge transfer

Fig. 4 Electronic structure of $\mathbf{N i}$ in $\mathbf{N i}_{\mathbf{3}} \mathbf{Z n}$ and $\mathbf{N i}_{\mathbf{3}} \mathbf{Z n C} \mathbf{C}_{\mathbf{0 . 7}}$ a Normalized Ni K-edge XANES spectra of NiO (pink curve), Ni foil (blue curve), Ni $\mathrm{Zn}$ (red curve), and $\mathrm{Ni}_{3} \mathrm{ZnC}_{0.7}$ (black curve), respectively. $\mathbf{b}$ In situ Ni K-edge XANES spectra during the process from $\mathrm{Ni}_{3} \mathrm{Zn}_{\mathrm{n}}$ to $\mathrm{Ni}_{3} \mathrm{ZnC}_{0.7}$ under 1.0 vol\% $\mathrm{C}_{2} \mathrm{H}_{2} / \mathrm{He}_{\mathrm{He}}$ atmosphere at $200^{\circ} \mathrm{C}$. c Charge density difference plots of the interface along [100] and [110] directions of $\mathrm{Ni}_{3} \mathrm{Zn}$ and $\mathrm{Ni}_{3} \mathrm{ZnC} \mathrm{C}_{0.7} . \mathbf{d}$ The charge density variation of $\mathrm{Ni}$ when transformed from $\mathrm{Ni}_{3} \mathrm{Zn}$ to $\mathrm{Ni}_{3} \mathrm{ZnC} \mathrm{C}_{0.7} . \Delta$ represents that the introduction of $\mathrm{C}$ to $\mathrm{Ni}_{3} \mathrm{Zn}$ renders $\mathrm{Ni}$ with an electron deficiency of -0.27 per atom.

subsequently lower down to $200^{\circ} \mathrm{C}$ and flushed with $\mathrm{He}$ for $30 \mathrm{~min}$. Then 1 vol\% $\mathrm{C}_{2} \mathrm{H}_{2} / \mathrm{He}$ atmosphere was switched into the in situ reaction cell, and the Ni K-edge XANES spectra were collected within $30 \mathrm{~min}$.

$\mathbf{H}_{\mathbf{2}}$ temperature-programmed desorption. $\mathrm{H}_{2}$-TPD experiments combined with on-line mass spectroscopy were conducted to evaluate the hydrogen adsorption/ absorption strength of $\mathrm{Ni} / \mathrm{oCNT}, \mathrm{Ni}_{3} \mathrm{Zn} / \mathrm{oCNT}$, and $\mathrm{Ni}_{3} \mathrm{ZnC}_{0.7} / \mathrm{oCNT}$ catalysts. Fifty milligrams of samples were pre-treated with a 10.0 vol\% $\mathrm{H}_{2} / \mathrm{He}$ mixture $\left(40 \mathrm{~mL} \mathrm{~min}^{-1}\right)$ at $500^{\circ} \mathrm{C}$ for $1 \mathrm{~h}$, switched to $\mathrm{He}\left(40 \mathrm{~mL} \mathrm{~min}^{-1}\right)$ to flush for $30 \mathrm{~min}$ after lowered down to room temperature. The $\mathrm{Ni}_{3} \mathrm{ZnC}_{0.7}$ catalyst was in situ prepared after hydrogen reduction. The mass signal of $M z=2$ was recorded at a heating rate of $10^{\circ} \mathrm{C} \mathrm{m^{-1 }}$ to $500^{\circ} \mathrm{C}$ for three samples.

Thermogravimetric analysis. TGA experiments were conducted by using a Netzsch-STA 449 F3 instrument. Fresh and spent catalysts $(\sim 1 \mathrm{mg})$ were treated in $50 \% \mathrm{O}_{2} / \mathrm{Ar}$ flow $\left(40 \mathrm{~mL} \mathrm{~min}{ }^{-1}\right)$ from 40 to $700{ }^{\circ} \mathrm{C}$ with a heating rate of $5^{\circ} \mathrm{C} \mathrm{min}^{-1}$.

TEM investigations. $\mathrm{Ni}_{3} \mathrm{Zn} / \mathrm{oCNT}$ and $\mathrm{Ni}_{3} \mathrm{ZnC}_{0,7} / \mathrm{oCNT}$ samples were dispersed and ultrasoniced in ethanol for $10 \mathrm{~min}$, and then a drop of the solution was placed on a holey $\mathrm{C} / \mathrm{Cu}$ TEM grid to be used for the TEM characterization. An FEI Tecnai $\mathrm{G}^{2}$ F20 microscope, JEM ARM200F and 300F Grand ARM Cs-corrected microscopes equipped with EDX and HAADF detectors were used to perform microstructural investigations of a series of $\mathrm{Ni}_{3} \mathrm{Zn} / \mathrm{oCNT}$ and $\mathrm{Ni}_{3} \mathrm{ZnC}_{0.7} /$ oCNT samples in both TEM and STEM modes.

Temperature-programmed surface reaction. TPSR of $\mathrm{C}_{2} \mathrm{H}_{2}$ on the Ni/oCNT and $\mathrm{Ni}_{3} \mathrm{Zn} / \mathrm{oCNT}$ sample were conducted with a quartz tubular microreactor connected to an on-line mass spectrometer. Fifty milligram samples were pre-treated with a 10.0 vol\% $\mathrm{H}_{2} / \mathrm{He}$ mixture $\left(40 \mathrm{~mL} \mathrm{~min}^{-1}\right)$ at $500{ }^{\circ} \mathrm{C}$ or $1 \mathrm{~h}$, switched to $\mathrm{He}\left(40 \mathrm{~mL} \mathrm{~min}^{-1}\right)$ to flush for $30 \mathrm{~min}$ after lower down to room temperature, then switched to $1.0 \mathrm{vol} \% \mathrm{C}_{2} \mathrm{H}_{2} / \mathrm{He}$ atmosphere $\left(40 \mathrm{~mL} \mathrm{~min}^{-1}\right)$. The mass signal of $M z=2$ was recorded at a heating rate of 4 and $10^{\circ} \mathrm{C} \mathrm{min}^{-1}$ to $200{ }^{\circ} \mathrm{C}$ for $\mathrm{Ni}$ and $\mathrm{Ni}_{3} \mathrm{Zn}$ samples, respectively.

Theoretical calculation. The DFT calculations were performed with Generalized Gradient Approximation using the Perdew-Burke-Ernzerhof (PBE) exchangecorrelation function. By using WIEN2k code, the charge density difference was calculated with a plane-wave cutoff parameter of $\mathrm{RK}_{\max }=7$ and 1000 points in the whole Brillouin zone. The bader charge analysis and geometric relaxation of $\mathrm{Ni}_{3} \mathrm{Zn}$ was implemented using the Vienna ab-initio simulation package (VASP). The kinetic energy cutoff of the plane-wave was set to be $400 \mathrm{eV}$, and the Brillouin zone was sampled by Monkhorst-Pack meshes of $9 \times 9 \times 9$ grid. Atomic position and lattice parameters of $\mathrm{Ni}_{3} \mathrm{Zn}$ were geometrically relaxed until changes in the total energy and force were less than $10^{-4} \mathrm{eV}$ and $5 \times 10^{-2} \mathrm{eV} \AA^{-1}$, respectively.

Catalytic tests. The acetylene selective hydrogenation in the excess of ethylene $\left(1.5,3.0,4.5,6.0\right.$, and $7.5 \mathrm{vol} \% \mathrm{H}_{2}, 20.0$ vol\% $\mathrm{C}_{2} \mathrm{H}_{4}, 0.5 \mathrm{vol} \% \mathrm{C}_{2} \mathrm{H}_{2}$, helium as balance) was performed in a fixed-bed quartz micro-reactor under atmospheric pressure. The $\mathrm{Ni}_{3} \mathrm{Zn} / \mathrm{oCNT}$ was in situ reduced and transformed to $\mathrm{Ni}_{3} \mathrm{ZnC}_{0.7} / \mathrm{oCNT}$ at $200^{\circ} \mathrm{C}$ under reaction conditions. For the stability test, the $\mathrm{Ni}_{3} \mathrm{ZnC}_{0.7} / \mathrm{oCNT}$ sample was in situ generated after reduction and carburization processes following $20 \mathrm{~mL} \mathrm{~min}^{-1} 50 \mathrm{vol} \% \mathrm{H}_{2} / \mathrm{He}$ treatment at $500^{\circ} \mathrm{C}$ for $2 \mathrm{~h}$ and $200{ }^{\circ} \mathrm{C} 1.0$ vol\% $\mathrm{C}_{2} \mathrm{H}_{2} / \mathrm{He}$ for $1 \mathrm{~h}$ before the reaction. Ni/oCNT catalyst was also in situ reduced at $500{ }^{\circ} \mathrm{C}$ for $2 \mathrm{~h}$ under $50 \mathrm{vol} \% \mathrm{H}_{2} / \mathrm{He}$ atmosphere before the test. 
The conversion (Conv) and selectively (Sele) were calculated as follows:

$$
\begin{gathered}
\operatorname{Conv}_{\mathrm{C}_{2} \mathrm{H}_{2}}=\frac{\mathrm{C}_{\mathrm{C}_{2} \mathrm{H}_{2}, \text { in }}-\mathrm{C}_{\mathrm{C}_{2} \mathrm{H}_{2}, \text { out }}}{\mathrm{C}_{\mathrm{C}_{2} \mathrm{H}_{2} \text {,in }}} \times 100 \%, \\
\text { Sele }_{\mathrm{C}_{2} \mathrm{H}_{4}}=\left(1-\frac{\mathrm{C}_{\mathrm{C}_{2} \mathrm{H}_{6} \text {,out }}}{\mathrm{C}_{\mathrm{C}_{2} \mathrm{H}_{2}, \text { in }}-\mathrm{C}_{\mathrm{C}_{2} \mathrm{H}_{2} \text {,out }}}\right) \times 100 \%,
\end{gathered}
$$

where $\mathrm{C}_{\text {in }}$ represents the acetylene concentration in the feed gas and $\mathrm{C}_{\text {out }}$ represents the different products in the outlet gas. Because of high concentration of the ethylene and the minor changes caused by the hydrogenation of acetylene was not easy to be detected, the consumption of the acetylene was assumed to be either hydrogenated to ethylene or hydrogenated to ethane.

\section{Data availability}

More experimental details and additional data can be found in the Supplementary Information (Supplementary Figs. 1-19 and Notes 1-4). All the relevant data are available from the corresponding author upon reasonable request. Source data are provided with this paper.

Received: 7 January 2020; Accepted: 12 June 2020;

Published online: 03 July 2020

\section{References}

1. Teschner, D. et al. The roles of subsurface carbon and hydrogen in palladiumcatalyzed alkyne hydrogenation. Science 320, 86-89 (2008).

2. Johnson, A. D., Daley, S. P., Utz, A. L. \& Ceyer, S. T. The chemistry of bulk hydrogen: reaction of hydrogen embedded in nickel with adsorbed $\mathrm{CH}_{3}$. Science 257, 223 (1992).

3. Ceyer, S. T. The unique chemistry of hydrogen beneath the surface: catalytic hydrogenation of hydrocarbons. Acc. Chem. Res. 34, 737-744 (2001).

4. Norskov, J. K., Bligaard, T., Rossmeisl, J. \& Christensen, C. H. Towards the computational design of solid catalysts. Nat. Chem. 1, 37-46 (2009).

5. Ruano, D. et al. Dynamic structure and subsurface oxygen formation of a working copper catalyst under methanol steam reforming conditions: an in situ time-resolved spectroscopic study. ACS Catal. 9, 2922-2930 (2019).

6. Pique, O. et al. Subsurface carbon: a general feature of noble metals. Angew. Chem. Int. Ed. 58, 1744-1748 (2019).

7. Bluhm, H. et al. Methanol oxidation on a copper catalyst investigated using in situ X-ray photoelectron spectroscopy. J. Phys. Chem. B 108, 14340-14347 (2004).

8. Blume, R. et al. Monitoring in situ catalytically active states of Ru catalysts for different methanol oxidation pathways. Phys. Chem. Chem. Phys. 9, 3648-3657 (2007).

9. Freund, H.-J., Meijer, G., Scheffler, M., Schlögl, R. \& Wolf, M. CO oxidation as a prototypical reaction for heterogeneous processes. Angew. Chem. Int. Ed. 50, 10064-10094 (2011).

10. Chan, C. W. et al. Interstitial modification of palladium nanoparticles with boron atoms as a green catalyst for selective hydrogenation. Nat. Commun. $\mathbf{5}$, 5787 (2014).

11. Chen, T. et al. Interstitial boron atoms in the palladium lattice of an industrial type of nanocatalyst: properties and structural modifications. J. Am. Chem. Soc. 141, 19616-19624 (2019).

12. Ellis, I. T. et al. Lithium and boron as interstitial palladium dopants for catalytic partial hydrogenation of acetylene. Chem. Commun. 53, 601-604 (2017).

13. Borodziński, A. \& Bond, G. C. Selective hydrogenation of ethyne in ethenerich streams on palladium catalysts. Part 1 . Effect of changes to the catalyst during reaction. Catal. Rev. Sci. Eng. 48, 91-144 (2006).

14. García-Mota, M., Bridier, B., Pérez-Ramírez, J. \& López, N. Interplay between carbon monoxide, hydrides, and carbides in selective alkyne hydrogenation on palladium. J. Catal. 273, 92-102 (2010).

15. Studt, F. et al. On the role of surface modifications of palladium catalysts in the selective hydrogenation of acetylene. Angew. Chem. Int. Ed. 47, 9299-9302 (2008).

16. Teschner, D. et al. Alkyne hydrogenation over Pd catalysts: a new paradigm. J. Catal. 242, 26-37 (2006)

17. Peña, J. A., Herguido, J., Guimon, C., Monzón, A. \& Santamaría, J. Hydrogenation of acetylene over $\mathrm{Ni} / \mathrm{NiAl}_{2} \mathrm{O}_{4}$ catalyst: characterization, coking, and reaction studies. J. Catal. 159, 313-322 (1996).

18. Bridier, B., López, N. \& Pérez-Ramírez, J. Partial hydrogenation of propyne over copper-based catalysts and comparison with nickel-based analogues. J. Catal. 269, 80-92 (2010).
19. Daley, S. P., Utz, A. L., Trautman, T. R. \& Ceyer, S. T. Ethylene hydrogenation on $\mathrm{Ni}(111)$ by bulk hydrogen. J. Am. Chem. Soc. 116, 6001-6002 (1994).

20. Viñes, F., Loschen, C., Illas, F. \& Neyman, K. M. Edge sites as a gate for subsurface carbon in palladium nanoparticles. J. Catal. 266, 59-63 (2009).

21. Chan, C. W. et al. New environmentally friendly catalysts containing Pdinterstitial carbon made from Pd-glucose precursors for ultraselective hydrogenations in the liquid phase. Chem. Commun. 47, 7971-7973 (2011).

22. Zhu, Y.-A., Dai, Y.-C., Chen, D. \& Yuan, W.-K. First-principles study of carbon diffusion in bulk nickel during the growth of fishbone-type carbon nanofibers. Carbon 45, 21-27 (2007).

23. Portnoi, V. K., Leonov, A. V., Mudretsova, S. N. \& Fedotov, S. A. Formation of nickel carbide in the course of deformation treatment of Ni-C mixtures. Phys. Met. Metallogr. 109, 153-161 (2010).

24. Gili, A. et al. Revealing the mechanism of multiwalled carbon nanotube growth on supported nickel nanoparticles by in situ synchrotron X-ray diffraction, density functional theory, and molecular dynamics simulations. ACS Catal. 9, 6999-7011 (2019).

25. Weatherup, R. S. et al. Interdependency of subsurface carbon distribution and graphene-catalyst interaction. J. Am. Chem. Soc. 136, 13698-13708 (2014).

26. Greeley, J., Krekelberg, W. P. \& Mavrikakis, M. Strain induced formation of subsurface species in transition metals. Angew. Chem. Int. Ed. 43, 4296-4300 (2004).

27. $\mathrm{Lu}, \mathrm{K}$. et al. Grain boundary plays a key role in carbon diffusion in carbon irons revealed by a ReaxFF study. J. Phys. Chem. C 122, 23191-23199 (2018).

28. Kang, J.-X. et al. Au catalyzed carbon diffusion in Ni: a case of lattice compatibility stabilized metastable intermediates. Adv. Funct. Mater. 28, 1706434 (2018).

29. Mishima, Y., Ochiai, S. \& Suzuki, T. Lattice parameters of $\mathrm{Ni}(\gamma), \mathrm{Ni}_{3} \mathrm{Al}\left(\gamma^{\gamma}\right)$ and $\mathrm{Ni}_{3} \mathrm{Ga}\left(\gamma^{c}\right)$ solid solutions with additions of transition and B-subgroup elements. Acta Metall. 33, 1161-1169 (1985).

30. Che, X.-L., Li, J.-H., Dai, Y. \& Liu, B.-X. Ab initio study on the structural stability and magnetism of metastable A3B phases in $\mathrm{Ni}-\mathrm{Au}(\mathrm{Cu}, \mathrm{Zn}, \mathrm{Al})$ binary systems. J. Phys. Soc. Jpn. 78, 034720 (2009).

31. Spanjers, C. S., Sim, R. S., Sturgis, N. P., Kabius, B. \& Rioux, R. M. In situ spectroscopic characterization of $\mathrm{Ni}_{1-\mathrm{x}} \mathrm{Zn}_{\mathrm{x}} / \mathrm{ZnO}$ catalysts and their selectivity for acetylene semihydrogenation in excess ethylene. ACS Catal. 5, 3304-3315 (2015).

32. Rinaldi, A. et al. Dissolved carbon controls the initial stages of nanocarbon growth. Angew. Chem. Int. Ed. 50, 3313-3317 (2011).

33. Su, D. S., Perathoner, S. \& Centi, G. Nanocarbons for the development of advanced catalysts. Chem. Rev. 113, 5782-5816 (2013).

34. Esconjauregui, S., Whelan, C. M. \& Maex, K. The reasons why metals catalyze the nucleation and growth of carbon nanotubes and other carbon nanomorphologies. Carbon 47, 659-669 (2009).

35. Helveg, S. et al. Atomic-scale imaging of carbon nanofibre growth. Nature 427, 426-429 (2004).

36. Borodziński, A. \& Bond, G. C. Selective hydrogenation of ethyne in ethenerich streams on palladium catalysts, Part 2: Steady-state kinetics and effects of palladium particle size, carbon monoxide, and promoters. Catal. Rev. Sci. Eng. 50, 379-469 (2008).

37. Mueller, J. E., van Duin, A. C. T. \& Goddard, W. A. Competing, coveragedependent decomposition pathways for $\mathrm{C}_{2} \mathrm{H}_{\mathrm{y}}$ species on nickel (111). J. Phys. Chem. C 114, 20028-20041 (2010).

38. Trimm, D. L., Liu, I. O. Y. \& Cant, N. W. The oligomerization of acetylene in hydrogen over $\mathrm{Ni} / \mathrm{SiO}_{2}$ catalysts: product distribution and pathways. J. Mol. Catal. A Chem. 288, 63-74 (2008).

39. Chen, Y. \& Chen, J. Selective hydrogenation of acetylene on $\mathrm{SiO}_{2}$ supported Ni-In bimetallic catalysts: promotional effect of In. Appl. Surf. Sci. 387, 16-27 (2016).

40. Mei, D., Neurock, M. \& Smith, C. M. Hydrogenation of acetylene-ethylene mixtures over Pd and Pd-Ag alloys: first-principles-based kinetic Monte Carlo simulations. J. Catal. 268, 181-195 (2009).

41. Benavidez, A. D. et al. Improved selectivity of carbon-supported palladium catalysts for the hydrogenation of acetylene in excess ethylene. Appl. Catal. A Gen. 482, 108-115 (2014).

42. Borodziński, A. \& Cybulski, A. The kinetic model of hydrogenation of acetylene-ethylene mixtures over palladium surface covered by carbonaceous deposits. Appl. Catal. A Gen. 198, 51-66 (2000).

43. Takht Ravanchi, M. \& Sahebdelfar, S. Pd- $\mathrm{Ag} / \mathrm{Al}_{2} \mathrm{O}_{3}$ catalyst: stages of deactivation in tail-end acetylene selective hydrogenation. Appl. Catal. A Gen. 525, 197-203 (2016).

44. Ahn, I. Y., Lee, J. H., Kim, S. K. \& Moon, S. H. Three-stage deactivation of Pd/ $\mathrm{SiO}_{2}$ and $\mathrm{Pd}-\mathrm{Ag} / \mathrm{SiO}_{2}$ catalysts during the selective hydrogenation of acetylene. Appl. Catal. A Gen. 360, 38-42 (2009).

45. McCue, A. J., Guerrero-Ruiz, A., Rodríguez-Ramos, I. \& Anderson, J. A. Palladium sulphide-a highly selective catalyst for the gas phase hydrogenation of alkynes to alkenes. J. Catal. 340, 10-16 (2016). 
46. McCue, A. J., Guerrero-Ruiz, A., Ramirez-Barria, C., Rodríguez-Ramos, I. \& Anderson, J. A. Selective hydrogenation of mixed alkyne/alkene streams at elevated pressure over a palladium sulfide catalyst. J. Catal. 355, 40-52 (2017).

47. Tang, W., Sanville, E. \& Henkelman, G. A grid-based Bader analysis algorithm without lattice bias. J. Phys. Condens. Mater. 21, 084204 (2009).

\section{Acknowledgements}

We gratefully acknowledge the financial support provided by the National Natural Science Foundation of China (21761132025, 21773269, 51932005, 91545119), LiaoNing Revitalization Talents Program (XLYC1807175), and Youth Innovation Promotion Association CAS (2015152). We also express our great thanks to the supports of the XAFS experiments from BSRF (Beijing Synchrotron Radiation Facility). We would like to dedicate this paper to Prof. Dang Sheng Su, who played an essential role in this work but unfortunately passed away just before the paper was submitted for publication.

\section{Author contributions}

Y.N. and B.Z. designed the experiments, and carried out structural and catalytic performance analysis. Y.N. and Y.W. prepared the $\mathrm{Ni}_{3} \mathrm{ZnC}_{0.7}$ catalysts and performed the reaction test experiments. J.C. conducted the theory calculation experiments. Y.N., X.H., M.-G.W., W.Z., and B.Z. conducted the Cs-corrected TEM experiments and structural analysis. Y.N. and S.X. conducted the in situ XRD experiments and structural analysis. Y.N., M.X., and M.W. conducted the in situ XAFS experiments and data analysis. Y.N., W.Z., M.W., and B.Z. conceived the project of interstitial atom catalysis design. All authors contributed to the discussions and manuscript preparation.

\section{Competing interests}

The authors declare no competing interests.

\section{Additional information}

Supplementary information is available for this paper at https://doi.org/10.1038/s41467020-17188-3.

Correspondence and requests for materials should be addressed to W.Z., M.W. or B.Z.

Peer review information Nature Communications thanks Alan J. McCue and the other, anonymous, reviewer(s) for their contribution to the peer review of this work.

Reprints and permission information is available at http://www.nature.com/reprints

Publisher's note Springer Nature remains neutral with regard to jurisdictional claims in published maps and institutional affiliations.

(c) (i) Open Access This article is licensed under a Creative Commons Attribution 4.0 International License, which permits use, sharing, adaptation, distribution and reproduction in any medium or format, as long as you give appropriate credit to the original author(s) and the source, provide a link to the Creative Commons license, and indicate if changes were made. The images or other third party material in this article are included in the article's Creative Commons license, unless indicated otherwise in a credit line to the material. If material is not included in the article's Creative Commons license and your intended use is not permitted by statutory regulation or exceeds the permitted use, you will need to obtain permission directly from the copyright holder. To view a copy of this license, visit http://creativecommons.org/ licenses/by/4.0/.

(c) The Author(s) 2020 